Article

\title{
Socio-Economic Opportunities from Miscanthus Cultivation in Marginal Land for Bioenergy
}

\author{
Calliope Panoutsou $1, *$ (1) and David Chiaramonti ${ }^{2,3}$ (1) \\ 1 Centre for Environmental Policy, Imperial College London, 16-18 Prince's Gardens, London SW7 1NE, UK \\ 2 "Galileo Ferraris" Energy Department, Polytechnic of Turin, Corso Duca degli Abruzzi 24, I-10129 Turin, \\ Italy; david.chiaramonti@polito.it \\ 3 RE-CORD, Polytechnic of Turin, Corso Duca degli Abruzzi 24, 10129 Torino, Italy \\ * Correspondence: c.panoutsou@imperial.ac.uk; Tel.: +44-755-734-1846
}

Received: 1 May 2020; Accepted: 25 May 2020; Published: 29 May 2020

\begin{abstract}
Substantial areas of agricultural land in south European countries are becoming increasingly marginal and being abandoned due to arid climate with prolonged summers and low rainfall. Perennial, lignocellulosic crops, such as Miscanthus, offer an outlet that couples agriculture with energy, creates employment, and increases profits from feedstock production in rural areas. This research paper follows an Input Output methodology and uses an econometric model to investigate the impact of crop yielding performance and marginal land to jobs and profit from the cultivation and supply of Miscanthus in low quality, marginal land in Italy and Greece. Two value chain cases are analysed: small scale Combined Heat and Power (CHP) and Fast Pyrolysis Bio Oil (FPBO). The cultivation of Miscanthus in both reference value chains exhibits good employment prospects, with smaller scale value chains creating more labour-intensive logistics operations. The activities can also generate substantial financial profit especially with higher crop yields. Results show a pronounced relationship between profitability and crop yield for both reference value chains-cultivation and supply operations become more profitable with increasing yield. It is, therefore, important to achieve higher yields through good cropping practices, while maintaining high levels of environmental sustainability.
\end{abstract}

Keywords: Miscanthus; Combined Heat and Power (CHP); Fast Pyrolysis Biomass Oil; marginal land; employment; profit; Italy; Greece

\section{Introduction}

Agriculture in south European countries faces increasing bio-physical and socio-economic limitations. Bio-physical limitations, including soil erosion [1], runoff and degradation that lead to soil organic carbon and fertility losses, relate mostly to climatic conditions [2] characterised by prolonged dry, hot summers and winters with low rainfall levels. These in turn lead to socio-economic limitations: lower crop yields and reduced competitiveness in national and international markets cause farmers to abandon the land and look for income opportunities in non-agricultural sectors.

For these reasons, it is imperative that crop options are diversified and new, locally adapted and climate resilient value chains, combined with sustainable agronomic practices, are introduced. Perennial, non-food, lignocellulosic crops, such as Miscanthus, can offer an outlet that couples agriculture with energy, generates employment and creates added value in rural areas [3-5]. These crops can grow on low quality land and therefore avoid or reduce competition with food production [6]. Moreover, they can exhibit high yields, have low environmental impact if cultivated in a sustainable way [7], improve soil carbon $[8,9]$, and be used for a variety of energy and other biobased products $[10,11]$.

This research paper presents the socio-economic impacts (employment generated and potential financial profit) from the cultivation and supply of Miscanthus in low quality, marginal land as 
feedstock for small scale Combined Heat and Power (CHP) (at scale $1 \mathrm{MW}$ electrical generation capacity) and Fast Pyrolysis Bio Oil (FPBO) (at scale 20,000 tonnes of oil output per year). The study considers low quality land which can be restored and cultivated with input of materials and irrigation, as required. The reference countries for present analysis of the value chains are Italy and Greece which have similarities in climate and where Miscanthus is well adapted [12-14] and exhibits similar yields. In these countries, there are several long-term experimental and demonstration experiments for Miscanthus [15-18], and labour and land costs are comparable. The selected value chains and their scales represent a set of 'crop end-use' combinations that are technically feasible and suitable to the ecology [19-21], climate, energy requirements and economy of the reference countries. The authors acknowledge that introducing perennial crops requires careful planning and collaboration with the local farming community. Adoption of such crops requires robust, enduring arrangements with farmers and local landowners who will be required to make long-term commitment [22,23]. Developing mutual trust among the stakeholders is needed along the entire value chain and is a key element for successful implementation.

A few recent papers published relevant research on this specific topic for south Europe. De la Rua and Lechon, (2016) [24] analysed the case of Miscanthus for bioenergy in France, by using an input output analysis of the economic sectors involved in the value chain. Chazara et al., (2017) [25] proposed an approach to measure the number of jobs and applied it to analyse the case of bioethanol in France. This paper presents new insights for the socio-economic opportunities of bioenergy in south Europe and introduces two new elements: i) cultivation of biomass in the form of perennial crops, in this case Miscanthus, in low quality marginal land for energy and fuels; ii) comparison of two end use markets at different scales i.e., small scale CHP (1 MW electric generation capacity) for local agro-industries and Fast Pyrolysis Bio Oil (FPBO) (20,000 tonnes per year oil output). FPBO is a biocrude that can be either upgraded to final transport fuels through catalytic hydrotreatment, or marketed as intermediate bioenergy carrier to relatively large biofuel producers, co-processed in existing refineries-in Fluid Catalytic Cracker reactors- or sold as a biochemical platform to derive various types of bio-based chemicals. The methodology is tailored to address considerations about the employment generation and the relationship between profitability and crop yield.

The scientific purpose of the work is to investigate the effect of crop yielding performance and marginal land to jobs and profit from the cultivation and supply of Miscanthus in low quality, marginal land in Italy and Greece. The first section provides the context for agriculture in the reference countries and justifies the rationale for the selection of Miscanthus. The second describes the modelling approach and main assumptions. The third presents the results in terms of employment and profit per value chain, per 1000 tonnes biomass produced and per million Euro invested. Finally, the fourth section discusses the main findings, their relevance to ongoing policy formation and provides concluding remarks.

Both the reference value chains can generate employment in the region and provide viable returns on investment, with acceptable rates of profit at low crop yield and good rates of profit at high crop yield. The data presented show a pronounced relationship between profitability and crop yield for both reference value chains - cultivation and supply operations become more profitable with increasing yield. The key conclusion is that it is important to achieve higher yields through good cropping practices, while maintaining high levels of environmental sustainability.

\section{Context}

Bio-physical parameters alongside socio-economic challenges during the last 20 years have led to substantial reduction of cultivated agricultural area and loss of farming jobs in Italy and Greece. This contributes to land abandonment and desertification and to increased migration to urban areas. 


\subsection{Agriculture in the Understudy Countries}

From 2000 to 2019, total cultivated agricultural area reduced by $26 \%$ in Italy, from 4.13 million ha to 3.07 million ha, and by $36 \%$ in Greece, from 1.22 million ha to 0.79 million ha (Figure 1). A similar decline is observed in the number of jobs. From 1995 to 2015, total number of jobs in agriculture reduced by $28 \%$ in Italy, from 1.26 million to 0.91 million, and by $38 \%$ in Greece, from 0.76 million to 0.47 million.

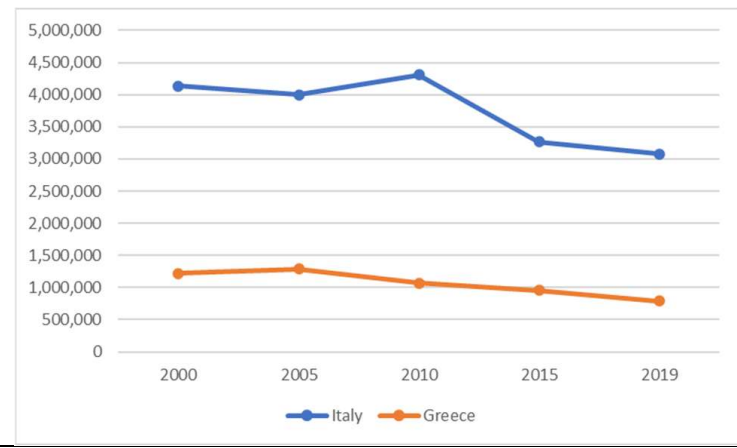

(a)

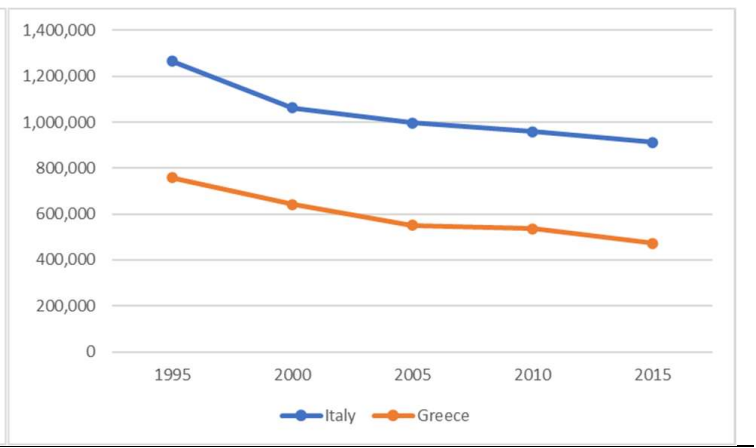

(b)

Figure 1. Reduction of agricultural cultivated area (in ha): (a) 2000-2019 and agricultural jobs; (b) 1995-2015 [26]) in Italy and Greece.

Both the Common Agricultural Policy and Renewable Energy Directive offer opportunities to support agriculture and farmers in rural areas of European regions. Their key policy objectives [27] and strategic priorities [28] include the development of biomass value chains that can restore 'areas

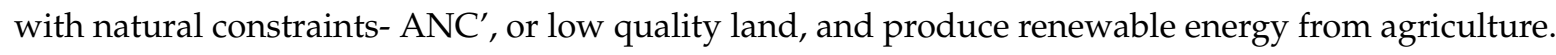

\subsection{Why Perennial Biomass Crops and Miscanthus?}

Recent research has examined various crop options that can be cultivated in low quality, marginal land and produce raw material for bioenergy and biofuels $[29,30]$. In particular, perennial lignocellulosic crops have characteristics that are suitable for such land that is affected by the ecological and climate limitations in the reference countries [31-33]. These include:

- Good adaptation. Perennial crops exhibit good adaptation to local climate and have high resistance to both biotic and abiotic stress, drought, high temperatures, pests, and diseases.

- Drought resistance for semi-arid and arid conditions. South European countries face prolonged dry periods during summer followed by heavy, short duration thunderstorms during autumn and winter. Hence, cropping solutions must exhibit high resistance to drought while maintaining sustainable growth patterns through these periods, and maintain their yields.

- Low irrigation and nitrogen inputs. Perennial crops have high nutrient [34] and water use efficiency [35], can grow with low or nil irrigation, and have low input requirements [36-38] relative to cereals. These characteristics make them attractive options for marginal land.

- Dense and deep rooting system. Perennial crops have dense rooting systems, [39], and are suitable for sloping, erosion-prone areas.

Miscanthus is [40] well adapted to south European countries, propagates via rhizomes, and often reaches a maximum height of 3-3.5 $\mathrm{m}$ [41]. It has low nutritional requirements and high nitrogen use efficiency and therefore can grow well on marginal land with relatively low inputs of fertiliser [42]. The crop shares similar growth characteristics other warm-season perennial species with growth from rhizomes, including switchgrass [43]. 


\subsection{Value Chains}

The reference value chains are suited to the climate, agronomy, and energy sector conditions in Italy [44-46] and Greece $[47,48]$. The scales and applications have been selected to reflect promising and realistic bioenergy options.

Small scale CHP: Using perennial crops as fuel for CHP plants can be an attractive solution for south European countries. A key requirement is local, heat demand. CHP plant must be located close to heat demands to minimise the high costs of heat distribution pipework. While there are many agro-industries that process materials that can use heat at this scale, a significant drawback is that installations typically operate seasonally. This may mean that the CHP plant is idle for part of the year, which reduces profitability. Peak heat demand will vary through the day and night, though this can be overcome by installation of thermal storage. Design, including appropriate sizing of the CHP, is important especially in view of the relatively high capital costs of this technology.

Fast Pyrolysis Bio Oil (FPBO): While production cost for advanced biofuels is still relatively high [49], demonstration and First Of A Kind (FOAK) plants are currently entering into commercial operation [50], and there will be cost reductions through the operation of larger plants that are under construction or planned. The most promising route today for FPBO-to-transport fuel is represented by co-processing in existing fossil refineries in Fluid Catalytic Cracker reactors. Moreover, FPBO use as bioliquid in CHP unit can also be an excellent approach to provide renewable-based balancing service to the energy system, and in particular to the electrical grid, thanks to the fact FPBO is a very convenient form of energy storage.

\subsection{SWOT Analysis}

Before estimating the potential employment and profit for the reference value chains, a screening was performed to evaluate their resource efficiency performance in the reference countries using Strengths-Weaknesses-Opportunities-Threats (SWOT) analysis. This assessed resource use efficiency, ecosystem aspects, business case and markets, and socio-economic aspects.

Perennial, non-food crops such as Miscanthus are considered a resource efficient option for south European countries since they are established once, have dense rooting systems, use low water and nutrient inputs and have high drought resistance. Perennial cropping reduces tillage and erosion risks $[51,52]$ and increases soil carbon. It must also be stressed that selection of appropriate species and land types is case and region specific and must consider local ecology and ensure that biodiversity is carefully preserved, and any risks of an invasive species is avoided. Final selection of crops determines the annual management practices, transportation, storage, and overall system efficiency to year round raw material supplies that guarantee smooth operation.

Table 1 presents an overview of performance and feedstock related strengths, opportunities, weaknesses, and threats [53] for Miscanthus in low quality, marginal land.

Table 2 presents the respective SWOT for the reference value chains. 
Table 1. SWOT for resource efficiency of the Miscanthus in low quality, marginal land.

\begin{tabular}{|c|c|c|}
\hline Criteria & Strengths and Opportunities & Weaknesses and Threats \\
\hline Land use productivity & $\begin{array}{l}\text { No direct competition with food/ feed as land is mostly marginal } \\
\text { and not currently in production }\end{array}$ & Low yielding capacity; Mostly uneconomic for farmers \\
\hline Land use change & $\begin{array}{l}\text { Limited if cultivated on land that is not suitable for arable crops } \\
\text { requiring higher quality soils. }\end{array}$ & \\
\hline Biodiversity & $\begin{array}{l}\text { Dale et al., (2010) report that Miscanthus, as a perennial crop can be } \\
\text { beneficial to biodiversity when appropriate crops are grown and } \\
\text { sustainably managed in suitable areas, especially degraded or } \\
\text { eroded land or when they are planted as buffers around } \\
\text { conventional annual crops since they can provide habitats to } \\
\text { various animals, and be used to filter nutrients or pollutants [54] }\end{array}$ & $\begin{array}{l}\text { Monoculture of any crop type is a threat to biodiversity. } \\
\text { Despite the fact that the understudy crops will be cultivated } \\
\text { in low quality, marginal land that is unsuitable for } \\
\text { conventional crops, it is important to ensure that a crop mix } \\
\text { appropriate for the local climate and ecology, is cultivated } \\
\text { and biodiversity is preserved. }\end{array}$ \\
\hline Soil & $\begin{array}{l}\text { Long-term presence in the field maintains soil structure, reduces } \\
\text { erosion risks, increases soil cover, favour soil aeration and } \\
\text { improves soil organic content. }\end{array}$ & $\begin{array}{l}\text { Increased fertiliser and other chemical inputs to achieve } \\
\text { adequate yields in marginal land, which depends on the } \\
\text { economic break-even point. }\end{array}$ \\
\hline Water quantity & $\begin{array}{c}\text { Higher lignin and cellulose contents in perennial grasses allow the } \\
\text { crop to stand upright at scarcity of water. } \\
\text { Deep roots allow more efficient use of water resources. }\end{array}$ & $\begin{array}{l}\text { Possibly high demand for irrigation during years with low } \\
\text { rainfall }\end{array}$ \\
\hline Markets and mobilisation & $\begin{array}{l}\text { Such land has a low or 'no' market value so any sustainable activity } \\
\text { bringing it back to productive state would be an improvement } \\
\text { towards access to markets and mobilisation of natural resources. }\end{array}$ & $\begin{array}{l}\text { Lack of strong communication channels with the } \\
\text { agricultural community. } \\
\text { Low flexibility for farmer (long terms commitment to a } \\
\text { single - or very few - customer(s)) to anticipate changing } \\
\text { markets and demand (e.g., shortage in food supply) }\end{array}$ \\
\hline
\end{tabular}


Table 2. Value chain related SWOT for resource efficiency.

\begin{tabular}{|c|c|c|c|c|}
\hline & \multicolumn{2}{|c|}{ Small Scale CHP } & \multicolumn{2}{|c|}{ Fast Pyrolysis } \\
\hline & Strengths/Opportunities & Weaknesses/Threats & Strengths/Opportunities & Weaknesses/Threats \\
\hline Energy efficiency & $\begin{array}{c}\text { Total efficiency of } 90 \% \text { can be } \\
\text { achieved with modern } \\
\text { systems }\end{array}$ & $\begin{array}{l}\text { Low heat loads; narrow heating } \\
\text { seasons }\end{array}$ & $\begin{array}{l}\text { High conversion efficiency } \\
\text { Co-processing possible }\end{array}$ & $\begin{array}{l}\text { Biocrude upgrading not yet fully } \\
\text { developed at industrial scale } \\
\text { Converting ash-rich material as } \\
\text { herbaceous crops is still a challenge } \\
\text { (low quality of Pyrolysis Oil PO) }\end{array}$ \\
\hline Output service & - & $\begin{array}{l}\text { Unit value of electricity is } \\
\text { higher than heat; however this } \\
\text { does not compensate the lower } \\
\text { conversion efficiency (compared } \\
\text { to heat-driven medium scale). }\end{array}$ & $\begin{array}{l}\text { Transport fuel and bioliquid for } \\
\text { stationary energy generation } \\
\text { (offering also balancing services } \\
\text { to the energy system) }\end{array}$ & - \\
\hline $\begin{array}{l}\text { Greenhouse gases/Air } \\
\text { quality }\end{array}$ & $\begin{array}{l}\text { Low input of fossil fuels; } \\
\text { GHG savings can be high }\end{array}$ & $\begin{array}{l}\text { Still higher Particle Matter (PM) } \\
\text { emissions than natural gas } \\
\text { combustion. }\end{array}$ & green Carbon; & - \\
\hline Business case & $\begin{array}{l}\text { Positive when full year } \\
\text { industrial heat demand. }\end{array}$ & - & - & Still subsidies needed \\
\hline
\end{tabular}




\section{Materials and Methods}

\subsection{Modelling Approach}

An econometric model has been used and tailored to calculate jobs across the value chain stages [55]. The methodological approach is based on input output (IO) analysis for activities in the relevant stages of the value chain [56]. The tables include technical and cost data, drawn from statistics, literature and expert opinion, for relevant activities, labour, materials and equipment at national, regional, and local (i.e., implementation) levels and describe flows in monetary terms across the value chain. The IO tables are divided into two main value chain components: (i) feedstock production (including logistics) and (ii) conversion technology (Table 3). Detailed information on the cost components, technical and economic input is presented in Appendix A.

The model follows the principles of Activity Based Costing (Figure 2). Based on information obtained from statistics, literature and expert opinion, the cost per unit is calculated by: (i) calculating the actual cost and overhead rates for each activity, (ii) allocating the cost of each activity to the products and (iii) allocating the total cost into production units.

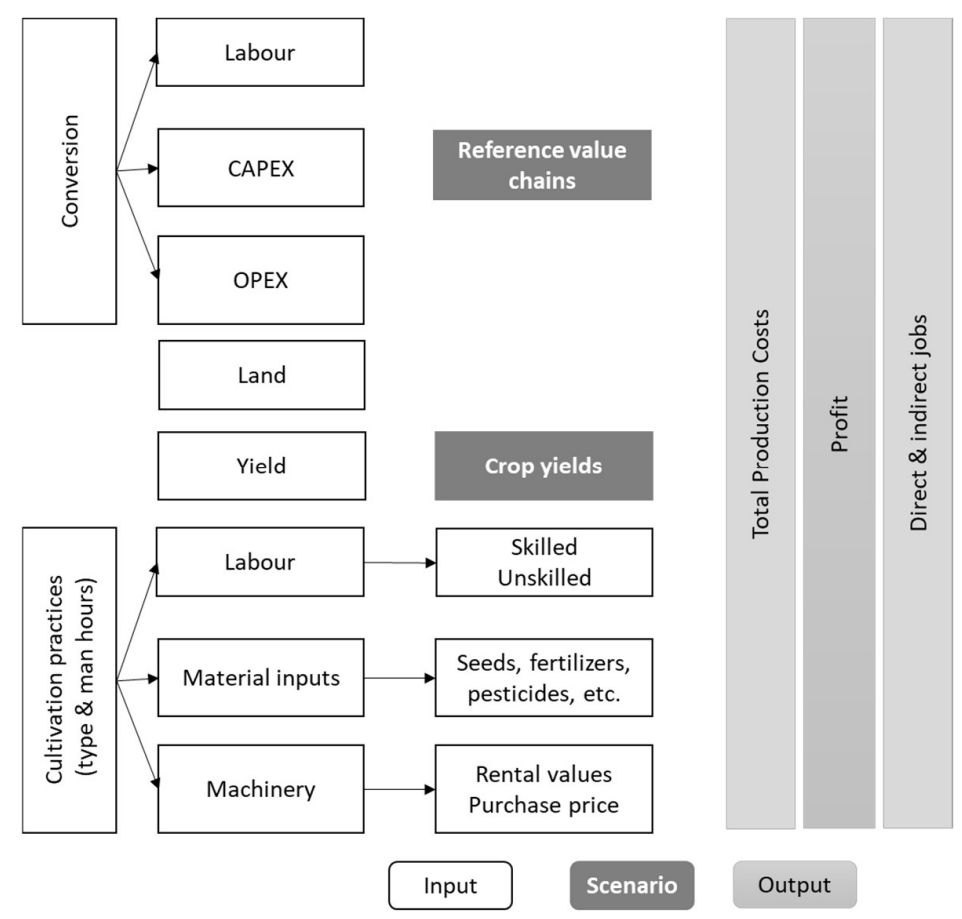

Figure 2. Model layout.

The tailored module for estimation of jobs and profit uses a traditional Keynesian Income Multiplier approach [57-59]. The technique calculates the employment and profits from all activities involved in the value chain.

The first part of the calculations is a financial assessment based on cash-flows over a fifteen-year period. The investment appraisal analyses the economic viability, within the specific scales of application for each value chain. This is important since investments will only be made if the plant is economically viable. Detailed technical and economic assumptions and input data are provided in Appendix A. 
Table 3. Input Output tables used in the modelling approach.

\begin{tabular}{|c|c|c|c|c|c|}
\hline & Category & Activities & Labour & Materials & Equipment \\
\hline \multirow{5}{*}{$\begin{array}{l}\text { Feedstock } \\
\text { production \& } \\
\text { logistics }\end{array}$} & Crop establishment & $\begin{array}{l}\text { Harrowing, initial herbiciding } \\
\text { and fertilising, planting/sowing }\end{array}$ & \multirow{2}{*}{$\begin{array}{c}\text { Regular farm labour } \\
\text { Contract/casual farm } \\
\text { labour Farmer/spouse } \\
\text { labour }\end{array}$} & $\begin{array}{l}\text { Fertilisers, herbicides, } \\
\text { seeds, cuttings, fuel }\end{array}$ & \multirow{2}{*}{$\begin{array}{c}\text { Tractor, Trailer Plough, } \\
\text { Sprayer, Disc Harrow, } \\
\text { Planter Fertiliser } \\
\text { distributor }\end{array}$} \\
\hline & Crop management & Spraying, fertilising, irrigation & & $\begin{array}{c}\text { Fertilisers, herbicides, } \\
\text { fuel }\end{array}$ & \\
\hline & Crop handling & Harvest, densification & Labourer & Fuel & Harvester, baler, chipper \\
\hline & Biomass storage & $\begin{array}{l}\text { Construction, operation, } \\
\text { maintenance }\end{array}$ & Labourer & Storage warehouse & - \\
\hline & Biomass transport & - & Transporter & & \\
\hline \multirow{2}{*}{ Conversion } & CAPEX Bioenergy Plant & $\begin{array}{l}\text { Land purchase, planning, } \\
\text { building, financial services, } \\
\text { environmental audit, legal }\end{array}$ & $\begin{array}{l}\text { Construction engineer } \\
\text { Construction labourer }\end{array}$ & & \\
\hline & OPEX Bioenergy Plant & $\begin{array}{l}\text { Maintenance and consumables } \\
\text { Feedstock costs Disposal costs } \\
\text { Annual maintenance Insurance }\end{array}$ & $\begin{array}{l}\text { Bioenergy plant operator } \\
\text { Bioenergy plant engineer }\end{array}$ & & \\
\hline
\end{tabular}


The second part, the socio-economic analysis, captures direct and indirect employment and profit potential for feedstock production, handling, and conversion. The calculations assume that biomass feedstock sales are based on long-term contracts with the energy/ fuel industry and therefore biomass production has a linear relation with sales. The employment presented in this paper is net direct and indirect and includes the following types of labour: regular farm labour, contract/casual farm labour, farmer/spouse labour, transport driver, construction plant engineer, construction plant labour, bioenergy plant operator and bioenergy plant engineer.

Direct jobs: Activities measured in the estimation of direct jobs created include crop establishment and annual management; plant construction, operation, and maintenance. The following Equation is used:

Direct Jobs $=$ Number of hours per worker/day/t of feedstock or end product . salary for the respective worker category

The formula integrates numbers of workers and type of their skills per individual production activity within the value chain.

Indirect jobs: In addition to direct jobs created across the value chain, indirect jobs are created by biomass handling, storage, transportation. The following Equation is used:

Indirect Jobs $=$ (annualised CAPEX - CAPEX of imported services and equipment $) /$ gross labour salaries (skilled and unskilled)

where annualised CAPEX includes costs from agronomic establishment and crop management practices.

CAPEX of imported services and equipment includes purchase or rent costs of equipment and any skilled labour required during the value chain activities.

The model estimates are presented in this paper as Full Time Employment equivalents (FTEs).

Annualised Profit is calculated with the following Equation:

Annualised Profit $(A P)=($ Sales Revenue $(S R)-$ Total Production Costs $(T P C)) /$ Project Lifetime $(P L)$

\subsection{Main Modelling Assumptions}

The average economic life cycle for Miscanthus is 15 years. Table 4 lists relevant agronomic input data [60-64].

Table 4. Agronomic characteristics for Miscanthus.

\begin{tabular}{|c|c|c|}
\hline Agronomic Characteristic & Miscanthus & References \\
\hline Economic Life & 15 years & [63-65] \\
\hline Land rent: & $(250 € / \mathrm{ha} / \mathrm{y}(\mathrm{IT}) / 220 € / \mathrm{ha} / \mathrm{y}(\mathrm{GR})$ & \\
\hline Growth type & Perennial & \\
\hline Establishment & Nov/Jan & \\
\hline Seedlings (number) & 10,000 & \\
\hline Seeds (t/ha) & 2.5 & {$[61,65]$} \\
\hline Harvest & $\mathrm{Nov} / \mathrm{Feb}$ & \\
\hline Yield (t/ha) & $10-17$ & {$[13,15,16,18,46,62]$} \\
\hline Soil type/pH (min-max) & $\begin{array}{l}\text { variety of soils-well drained } \\
\qquad(4.5-8.0)\end{array}$ & \\
\hline \multicolumn{2}{|c|}{ Fertilisers (annual avg. for life cycle) $[\mathrm{kg} /(\mathrm{h} \times \mathrm{yr})]$} & {$[18,48]$} \\
\hline $\mathrm{N}$ & 38 & \\
\hline $\mathrm{P}_{2} \mathrm{O}_{5}$ & 16 & \\
\hline $\mathrm{K}_{2} \mathrm{O}$ & 102 & \\
\hline $\mathrm{CaO}$ & 31 & \\
\hline $\begin{array}{l}\text { Water demand (combination of } \\
\text { rainfall and irrigation depending on } \\
\text { the specific region) }\left[\mathrm{m}^{3} /(\mathrm{ha} \times \mathrm{yr})\right]\end{array}$ & 5500 & {$[18,48]$} \\
\hline
\end{tabular}


The values are based on actual field experiments and are complemented with recent findings from literature to ensure values are representative and up to date. Drying for Miscanthus after an annual harvest to enable stable year round storage is also considered and the cost relevant data related to storage are included in Appendix A (Table A3).

The analysis in this paper uses Miscanthus but switchgrass can also be regarded with similar proxies as the two crops have similar agriculture cycle, compatibility with existing machinery and similar cost structure. There is good agronomic knowledge for both crops, and they can be cultivated using existing machinery which eases their adoption by farmers. Care would need to be taken for further application of the model for crops which differ substantially in their key characteristics from the reference crop or for production processes located in countries with different economic structures to Italy and Greece [6].

Conversion technologies need to be checked against specific properties such as ash, etc. versus technology requirements. One can distinguish primarily combustion systems, gasification or pyrolysis combined with production of heat and/or electricity, gasification or pyrolysis combined with upgrading or synthesis to biofuels/chemicals and biochemical treatment to biofuels/chemicals $[65,66]$. Two value chains are analysed within in this paper: small and large-scale CHP and upgraded fast pyrolysis biomass oil. These represent a mix of scales and applications that are suitable for conditions in south European countries. Their technical and economic assumptions are briefly described below and in Table 5.

Small scale CHP: This pathway is attractive for agro-industries and other industries with close relevance to biomass [67-71]. Small scale is clearly heat-driven, particularly if it refers to process heat. The conventional reference product for both heat and electricity is that produced via combustion of a fossil energy carrier in a boiler (natural gas or light fuel oil).

Upgraded or co-processed pyrolysis oil: The major advantages of pyrolysis oil include its storability, high energy density compared to raw biomass, and flexibility with respect to downstream processing and use options [72]. Furthermore, lignocellulosic biomass may serve as feedstock resulting in advantageously interlinkages with food and feed markets. There are several studies for pyrolysis of Miscanthus and similar crops, which show these are suitable feedstocks for this process [73-80]. The production of upgraded pyrolysis oil mainly consists of the two processes fast pyrolysis and upgrading, which both can occur in one integrated plant. Biomass feedstock first undergoes fast pyrolysis. Then, by upgrading, crude pyrolysis oil becomes suitable for several applications. So far, the explored concepts are about smaller scale decentralised flash pyrolysis, followed by central upgrading. These applications include heating, fuels for transportation and bio-based materials. In any of these cases, the upgraded pyrolysis oil substitutes light fuel oil. Upgrading depends on the end use. For heating oil there are less stringent requirements than for transport fuel, even if burners still need to be adapted to the viscous and corrosive nature of FPBO. Since the latter two options may have certain technical restrictions or may require certain process modifications, the assessment in this paper is based on the combustion of upgraded pyrolysis oil instead of light fuel oil in a boiler. Recently research is oriented towards co-processing of FPBO in existing refineries: this is carried out in Fluid Catalytic Crackers of existing refineries, where FPBO is co-fed with Virgin Gas Oil [81]. This is today seen among the most promising short-term routes to transport fuel production from the Fast Pyrolysis (FP) biocrude [82,83]. Methods are also being developed for accounting the amount of renewable carbon ending in the final transport fuel product, which is a very important aspect from a regulatory perspective.

Table 5 provides the technical and economic assumptions used for the reference value chains to estimate the employment effects.

Sensitivity analyses the potential yield increases in the profitability of the bioenergy plants as well as on respective values for income and employment from feedstock production and handling. 
Table 5. Techno-economic assumptions for modelling the understudy value chains.

\begin{tabular}{ccccc}
\hline Title & Scale & $\begin{array}{c}\text { Biomass Required } \\
\text { (Dry Tonnes with } \\
\mathbf{2 0 \%} \text { Moisture) }\end{array}$ & $\begin{array}{c}\text { Installation } \\
\text { Costs/(€2018/kWth) }\end{array}$ & $\begin{array}{c}\text { O\&M Costs } \\
\text { (€2018/GJ) }\end{array}$ \\
\hline CHP (small) & $1 \mathrm{MWe}$ & 5500 & 1000 & 27.5 \\
Pyrolysis oil & 20,000 t/y of FPBO & 30,000 & $1000[84]$ & 3 \\
\hline
\end{tabular}

\section{Results}

The results present model estimates for employment and profit generated by feedstock production and logistics for the two value chains under a range of yields (10-15 dry tonnes/ha/year) in low quality, marginal land [85-87]. Most research and demonstration fields with Miscanthus in low quality land exhibits yields of 8-17 dry tonnes/ha/year [88]. This paper uses a range 10-15 dry tonnes/ha/year, which excludes some of the least and best performing sites. Within this range the reference value chains are profitable investment opportunities in both Italy and Greece. The crop selling price that has been used across the modelling estimations for all yielding capacities and value chains is 100 Euro/dry tonne delivered at the plant gate $[89,90]$.

\subsection{Employment}

This section presents the employment potential from feedstock production for the two reference value chains. The labour required is seasonal. Therefore, as reported by ETI (2017) 'most job opportunities will be part-time, but may complement other seasonal roles in agricultural and forestry sectors, particularly arable farming with cereals' [91] (Figure 3).

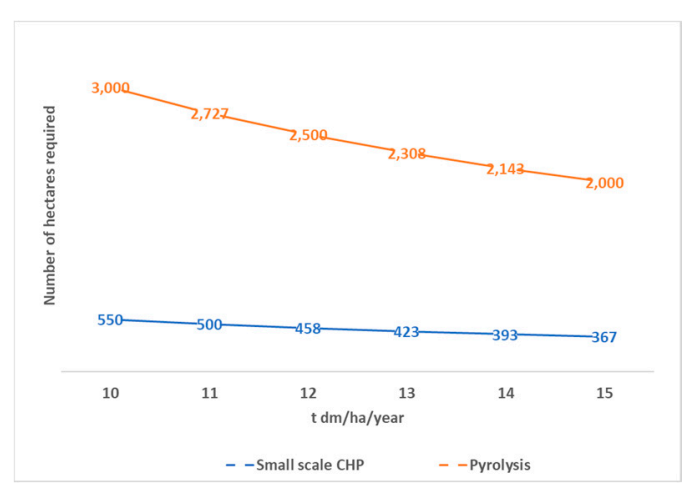

(a)

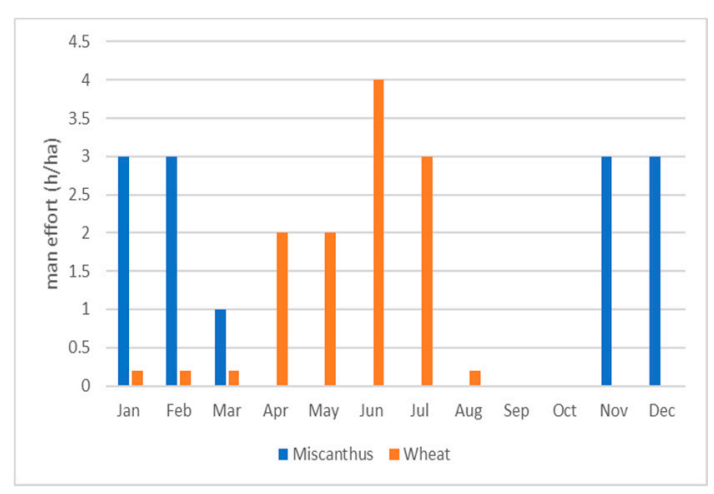

(b)

Figure 3. (a) Area (in ha) required for crop cultivation per value chain and crop yielding capacity and (b) on-farm monthly labour requirements (in man hours/ha) for maintaining and harvesting the crop on an annual basis (excludes establishment).

This paper presents employment potential from feedstock production as direct and indirect Full Time Employment equivalents [92] (FTE). Estimated employment is also represented per 1000 tonnes biomass input and per million Euro investment.

Figure 3 below presents the area (in hectares) required for each value chain depending on crop yield and the crop labour profiles (man effort in hours/ha) distributed monthly in comparison to wheat. Miscanthus cultivation can complement well with agricultural activities over the year in regions with wheat or other cereal crops.

\subsubsection{Employment Potential per Value Chain}

Employment generated per pyrolysis value chain is estimated to be 18-28 direct FTEs plus 122-182 indirect FTEs, depending on crop yield. Employment generated per small scale CHP value chain is 
estimated to be 2-3 direct FTEs plus 22-33 indirect FTEs, depending on crop yield. Table 6 provides the detailed figures, disaggregated in direct and indirect jobs for feedstock production and handling, per crop yielding capacity and value chain.

Table 6. Full Time Employment equivalents per value chain for different crop yields (indirect FTEs in brackets).

\begin{tabular}{ccccccc}
\hline $\mathbf{t} \mathbf{~ d m} / \mathbf{h a} / \mathbf{y})$ & $\mathbf{1 0}$ & $\mathbf{1 1}$ & $\mathbf{1 2}$ & $\mathbf{1 3}$ & $\mathbf{1 4}$ & $\mathbf{1 5}$ \\
\hline $1 \mathrm{MWe}$ Small scale CHP & $3(33)$ & $3(30)$ & $3(28)$ & $2(26)$ & $2(24)$ & $2(22)$ \\
20,000 t/y FPBO Pyrolysis & $28(182)$ & $25(166)$ & $23(152)$ & $21(140)$ & $20(130)$ & $18(122)$ \\
\hline
\end{tabular}

In addition to the above, employment is created in the operation of the conversion plant for each reference value chain. Additional employment per pyrolysis value chain is estimated to be three direct FTEs plus nine indirect FTEs. Additional employment per small scale CHP value chain is estimated to be two direct FTEs plus 6sixindirect FTEs.

\subsubsection{Employment Potential per 1000 Tonnes of Biomass Input and per ha}

Employment potential in small scale CHP for the higher crop yields $(15 \mathrm{t} \mathrm{dm} / \mathrm{ha} / \mathrm{y})$ is estimated at 5.3 FTEs (total direct and indirect) over the lifetime of the value chain per 1000 tonnes of biomass produced, handled and delivered to the plant gate. For lower crop yields $(10 \mathrm{tdm} / \mathrm{ha} / \mathrm{y})$, employment is estimated at 2.2 FTEs for per 1000 tonnes of biomass. The respective numbers for the pyrolysis value chain range from 1.6 FTEs for the higher crop yields to 2 FTEs for the for the lower crop yields.

Direct job FTEs per cultivated hectare for an average yield of $12 \mathrm{tdm} / \mathrm{ha} /$ year are estimated to be 0.0018 and 0.0016 for pyrolysis and small scale CHP value chains, respectively. These figures align with the work presented by Thornley et al. (2008) who reported 0.0014 FTEs per hectare for Miscanthus production on average farming land conditions. The slightly higher figures in this paper can be attributed firstly to the small scale of the CHP value chain, which is relatively inefficient in employment terms, and secondly to the fact that the land considered is low quality and requires more labour-intensive practices.

It is notable that supplying an equivalent amount of biomass to many small scale plants versus one larger plant generates a larger number of jobs because the former would likely engage a large number of small agricultural companies and farms would be less mechanised and efficient, and thus would employ more people.

Overall, on an equivalent volume of biomass basis, it is estimated that smaller scale CHP value chains generates 1.3-2.5 times more local employment within a region than pyrolysis value chains (depending on the scale and crop yields). Smaller value chains will create medium scale transport, storage and distribution channels with lower efficiencies than the national and international scale logistics created under pyrolysis value chains.

\subsubsection{Employment Potential per Million Euro Investment}

Figure 4 presents the leverage capacity of the value chains in terms of employment (direct and indirect) per million Euro investment.

Total FTEs per million E; uro investment range from 4.1 to6.1 and from 7.3 to 11 for pyrolysis and small scale CHP respectively. For small scale CHP, estimated direct FTEs range from 0.6 for high crop yields $(15 \mathrm{tdm} / \mathrm{ha} / \mathrm{y})$ to 1.0 for low crop yields $(10 \mathrm{t} \mathrm{dm} / \mathrm{ha} / \mathrm{y})$. For pyrolysis, the figures are very similar and are 0.7 and 1.1, respectively. For small CHP, the estimated indirect FTEs range from 7.3 for high crop yield to 11 for low crop yield. For pyrolysis, the figures are from 4.1 to 6.1 respectively. It is worth noting that direct FTEs are almost identical as they refer to the employment for cultivating the fields and harvesting while the significant differences in the estimated indirect FTEs include logistics, services and raw material purchase and in a way reflect the inefficiencies of small 
scale and low yields resulting in many more farms engaged for the provision of year round supplies in the refence value chains. As mentioned above, smaller scale value chains create more labour-intensive logistics operations.

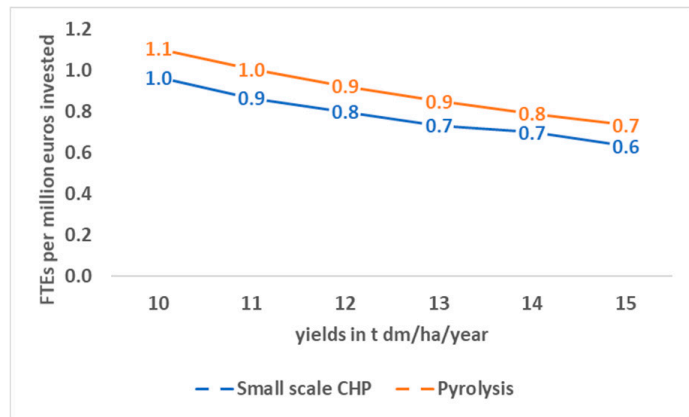

(a)

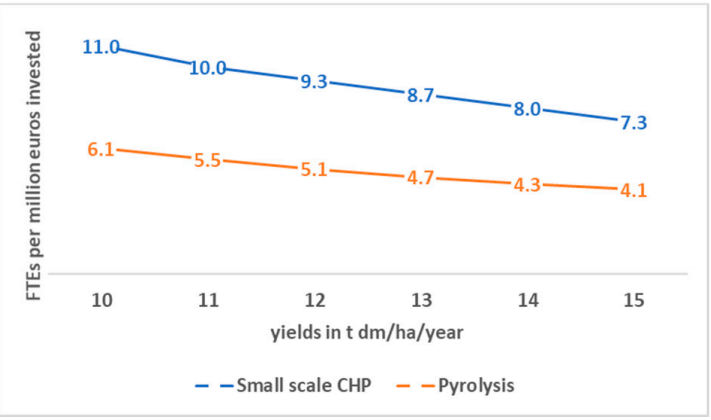

(b)

Figure 4. Net additional FTEs per million Euro investment in the reference value chains by crop yield:

(a) direct and (b) indirect respectively).

Direct employment in the downstream, conversion plant is estimated to be two FTEs for small scale CHP and four FTEs for pyrolysis. The respective, estimated indirect jobs are six FTEs for small scale CHP and nine FTEs for pyrolysis. The number of direct and indirect FTEs are within a similar range to estimates for bioenergy in the USA [93] and in Europe [94].

\subsection{Profit from the Sales of Biomass}

This section presents the potential annual profit from Miscanthus cultivation for each of the value chains. The model estimates are presented per value chain and per million Euro investment.

\subsubsection{Profit per Value Chain}

Total annual profit from feedstock production and handling for the small scale CHP value chain ranges from 38,000 € for low crop yield ( $10 \mathrm{t} \mathrm{dm} / \mathrm{ha} / \mathrm{y}$ ) to $268,000 €$ for high crop yield ( $15 \mathrm{t} \mathrm{dm} / \mathrm{ha} / \mathrm{y}$ ). For pyrolysis, the figures are $373,800 €$ for low crop yield to $1,570,000 €$ for high crop yield. Table 7 summarises modelled estimated annual profit and details are provided in Appendix B.

Table 7. Added value for the region in terms of annual profit (in $€$ ) from the cultivation of Miscanthus per value chain for different crop yields.

\begin{tabular}{ccccccc}
\hline Value Chain & $\mathbf{1 0}$ & $\mathbf{1 1}$ & $\mathbf{1 2}$ & $\mathbf{1 3}$ & $\mathbf{1 4}$ & $\mathbf{1 5}$ \\
\hline 1 MWe Small scale CHP & 38,000 & 100,800 & 153,000 & 197,300 & 235,200 & 268,000 \\
20,000 t/y FPBO Pyrolysis & 374,000 & 701,000 & 973,200 & $1,203,800$ & $1,401,000$ & $1,572,600$ \\
\hline
\end{tabular}

\subsubsection{Profit per Million Euro Investment}

For small scale CHP applications, total annual profit per million Euro investment is estimated to range from 0.2 million $€$ for low crop yield to 1.4 million $€$ for high crop yield (Figure 5). For pyrolysis, figures range from 0.2 million $€$ for low crop yield to 1.0 million $€$ for high crop yield. 


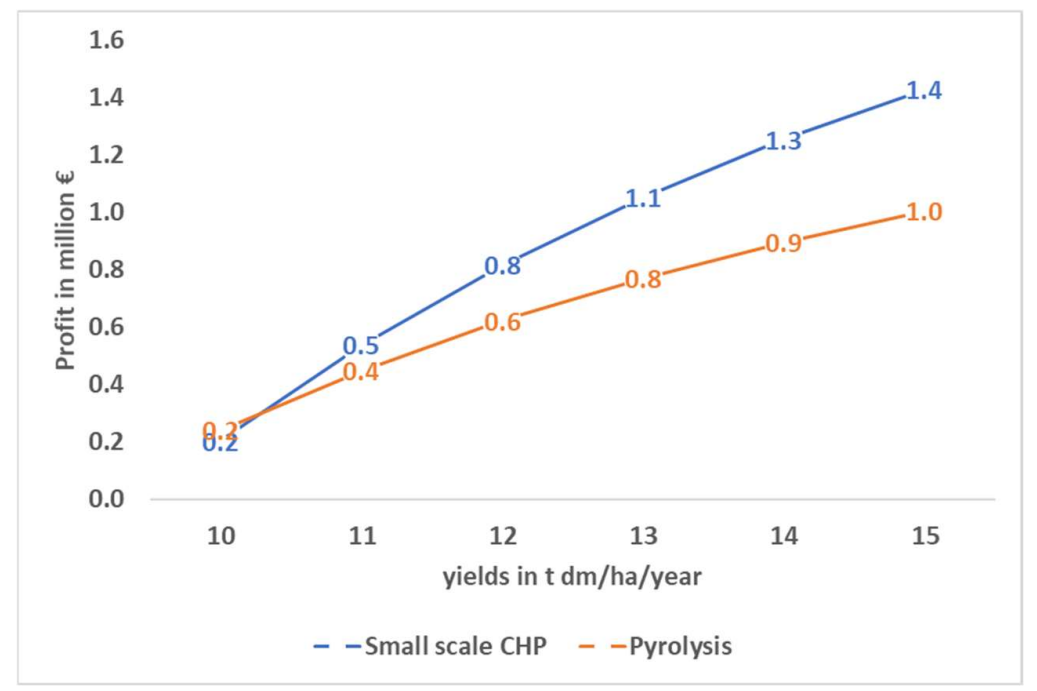

Figure 5. Annual profit (million $€$ ) per million Euro investment in the two reference value chains by crop yield.

\section{Discussion}

Biomass production for energy and alternative fuels is central to European policy for energy and agriculture. There are, however, concerns regarding the environmental sustainability of biomass supply and optimal solutions for increasing feedstocks and securing long-term, year round supplies for current operational and future plants. Renewable Energy Directive II (REDII) emphasises the role of biofuels, bioliquids and biomass fuels and, at the same time, ensures sustainability is safeguarded and Indirect Land Use Change (ILUC) impacts associated with conventional pathways are reduced. Significant expansion of production of biofuels, bioliquids and biomass fuels from food and feed crops and from land with high carbon stock was observed [95]. Hence, over the period from 2024 to 2030, these practices will be phased out. This provides significant opportunities to integrate non-food, lignocellulosic crops such as Miscanthus into European agricultural systems to provide feedstocks for energy and fuels.

The Directive, through the Commission Delegated Regulation (EU) 2019/807 of 13 March 2019 [96], encourages production of biomass raw materials that are produced under circumstances that avoid ILUC effects, by virtue of having been cultivated on unused, abandoned or severely degraded land or emanating from crops which benefited from improved agricultural practices. This definition offers the opportunity to restore low quality, marginal land, bridge the gap between agriculture and energy, and deliver low carbon solutions with high resilience to climate change.

This paper investigates the effect of crop yielding performance and marginal land to jobs and profit from the cultivation and supply of Miscanthus in low quality, marginal land in Italy and Greece. It presents research work which is supported by extensive modelling and consistent datasets from statistics, literature, and personal communication.

The work confirms that there are opportunities to generate employment and create financial profit from cultivation and supply of Miscanthus using low quality, marginal land in Italy and Greece. Two reference value chains have been analysed: small scale CHP (1 MWe) and Fast Pyrolysis Bio Oil plant (20,000 tonnes oil/year). These represent a set of 'crop end-use' combinations that are technically feasible and suitable to the ecology, climate, energy requirements and economy of the reference countries.

Generation of employment and creation of profit per million Euro investment is a key metric for both policy decision makers and investors. On this metric, the results are as follows. For CHP, total jobs (direct plus indirect) are 12.0 FTE and 7.9 FTE and annual profit is $0.2 \mathrm{~m} €$ and $1.4 \mathrm{~m} €$ for low and high crop yield, respectively. For pyrolysis, total jobs are 7.2 FTE and 4.8 FTE and annual profit is $0.2 \mathrm{~m} €$ and $1.0 \mathrm{~m} €$ for low and high crop yield, respectively. 
Direct FTEs refer to the employment for cultivating the fields and harvesting while indirect FTEs relate to other services including seed and plantlet producers, feedstock handling and transport, storage, fertiliser producers and suppliers, specialist equipment contractors, etc. Indirect jobs are much more numerous than direct jobs. Small scale operations (for the CHP value chain) and lower crop yields (for both reference value chains) result in more land and farms involved in cultivation and consequently more direct jobs. The impact in terms of indirect jobs is more pronounced, with small scale operations and lower yields necessitating many more indirect jobs. These relationships are quantified by the data presented in this paper.

Both the reference value chains appear to provide viable returns on investment, with acceptable rates of profit at low crop yield and good rates of profit at high crop yield. The data presented show a pronounced relationship between profitability and crop yield for both reference value chains-cultivation and supply operations become more profitable with increasing yield.

\section{Conclusions}

The general conclusion from the research findings of this paper is that there are opportunities to generate employment and create financial profit from cultivation and supply of Miscanthus using low quality, marginal land. The approach used can be applied by other researchers, policy makers and other stakeholders to evaluate the effect of yields and quality of land on future lignocellulosic crop options for bioenergy, compare cases and quantify impacts in terms of employment and profit.

The results confirm that financial profit has a strong, positive relationship with crop yield. At the lowest crop yield considered in this paper $(10 \mathrm{tdm} / \mathrm{ha} / \mathrm{y})$, annual profit is modest. A key conclusion is that it is important to achieve higher yields which will require good cropping practices, while maintaining high levels of environmental sustainability. Although this is a challenge on low quality land, experiments have shown that yields of 13-15/t/ha/y can be achieved in Italy and Greece. The choice of land and agricultural management practices, including targeted irrigation, will be critical for achieving higher yields.

The estimates provided in this paper can also be used as background knowledge to inform two main sets of policy, the Renewable Energy Directive II (REDII) [97] and the fourth objective of the Common Agricultural Policy post 2020 (CAP) [98]. This objective aims to contribute to climate change mitigation and adaptation, as well as sustainable energy, and can be combined with the Renewable Energy Directive at national level to develop sector integrated biomass policies [99].

Common Agricultural Policy (CAP) post 2020 will be based on assessment of needs at national level. EU Member States will therefore design their CAP Strategic Plans to achieve common environmental and climate change objectives, set quantified targets, and take specific local needs and conditions into consideration. The approach and data presented in this paper can inform future research about employment and added value in terms of financial profit from cultivation and supply of Miscanthus using low quality, marginal land and facilitate target-setting tailored to local conditions.

Author Contributions: Conceptualization, C.P. and D.C.; Methodology, C.P. and D.C.; Validation, C.P. and D.C.; Formal Analysis, C.P. and D.C.; Investigation, C.P. and D.C.; Resources, C.P. and D.C.; Data Curation, C.P. and D.C.; Writing-Original Draft Preparation, C.P. and D.C.; Writing-Review \& Editing, C.P. and D.C. All authors have read and agreed to the published version of the manuscript.

Funding: "This research was funded by the European Commission, in Biomass Policies, grant number (SI2.64592)" and in S2Biom, grant number (608622).

Conflicts of Interest: The authors declare no conflict of interest. 


\section{Appendix A. Input Parameters}

Table A1. Feedstock production data: Crop establishment.

\begin{tabular}{|c|c|c|c|c|c|c|}
\hline Variable & Value & Units & Lab, mats, & If yes & If no, were & If yes, \\
\hline & & & $\begin{array}{l}\text { machinery from } \\
\text { region? }\end{array}$ & what $\%$ ? & $\begin{array}{c}\text { from } \\
\text { country? }\end{array}$ & what $\%$ ? \\
\hline Labour & Farmer & type & yes & 70 & yes & 30 \\
\hline Average Land Rent & 250 & $€ /$ ha & yes & 70 & yes & 30 \\
\hline Seeds/cuttings & 100 & $\%$ & yes & 70 & yes & 30 \\
\hline Cost of seeds/cuttings & 25 & $€ / \mathrm{kg}$ & & & & \\
\hline Planting density & 2500 & $\mathrm{~kg} / \mathrm{ha}$ & & & & \\
\hline Time sub-soiling & 2 & h/ha & & & & \\
\hline Time ploughing & 3 & h/ha & & & & \\
\hline Time harrowing & 2 & h/ha & & & & \\
\hline Time disking & 1 & h/ha & & & & \\
\hline Time planting & 2 & h/ha & & & & \\
\hline Cost of spray & 15 & $€ / \mathrm{kg}$ & no & 0 & yes & 50 \\
\hline Application & 2 & $\mathrm{~kg} / \mathrm{ha}$ & & & & \\
\hline Time spraying & 1 & $\mathrm{~h} / \mathrm{ha}$ & & & & \\
\hline Fertiliser type & inorganic & type & no & 0 & yes & 70 \\
\hline Cost of fertiliser & 50 & $€ / \mathrm{kg}$ & & & & \\
\hline Application & 100 & $\mathrm{~kg} / \mathrm{ha}$ & & & & \\
\hline Time fertilising & 2 & h/ha & & & & \\
\hline
\end{tabular}

Table A2. Feedstock production: Crop management and harvest.

\begin{tabular}{|c|c|c|c|c|c|c|}
\hline Variable & Value & Units & Lab, mats, & If yes & If no, were & If yes, \\
\hline & & & $\begin{array}{l}\text { machinery from } \\
\text { region? }\end{array}$ & what $\% ?$ & $\begin{array}{l}\text { from } \\
\text { country? }\end{array}$ & what $\%$ ? \\
\hline Labour & Regular & type & yes & 100 & no & 0 \\
\hline Cost of spray & 15 & $€ / \mathrm{kg}$ & & & & \\
\hline Application & 2 & $\mathrm{~kg} / \mathrm{ha}$ & & & & \\
\hline Time spraying & 1 & $\mathrm{~h} / \mathrm{ha}$ & & & & \\
\hline Fertiliser type & Inorganic & type & no & 0 & yes & 70 \\
\hline Cost of fertiliser & 0.3 & $€ / \mathrm{kg}$ & & & & \\
\hline Application & 50 & $\mathrm{~kg} / \mathrm{ha}$ & & & & \\
\hline Time fertilising & 0.5 & $\mathrm{~h} / \mathrm{ha}$ & & & & \\
\hline Irrigation capital costs & 1000 & $€ /$ ha & & & & \\
\hline Time irrigating & 10 & h/ha & & & & \\
\hline Harvester & forage & type & yes & 50 & yes & 50 \\
\hline Time to harvest & 0.13 & $h / t$ & & & & \\
\hline Time to harvest & 4 & h/ha & & & & \\
\hline Harvesting interval & 1 & years & & & & \\
\hline
\end{tabular}

Table A3. Feedstock production data: Crop/Biomass storage and transport to the conversion plant.

\begin{tabular}{|c|c|c|c|c|c|c|}
\hline Variable & Value & Units & Lab, mats, & If yes & If no, were & If yes, \\
\hline & & & $\begin{array}{l}\text { machinery from } \\
\text { region? }\end{array}$ & what $\%$ ? & $\begin{array}{c}\text { from } \\
\text { country? }\end{array}$ & what $\%$ ? \\
\hline Labour & Regular & type & yes & 100 & no & 0 \\
\hline Time caretaking storage & 10 & $\mathrm{~h} / \mathrm{y}$ & yes & 100 & no & 0 \\
\hline Storage method & field & type & yes & 100 & no & 0 \\
\hline Cost of storage construction & 50,000 & $€ /$ ha & & & & \\
\hline Life of storage building & 100 & years & & & & \\
\hline Storage capacity required & 24.55 & t/ha & & & & \\
\hline Labour & driver & type & yes & 100 & no & 0 \\
\hline Transporter & curtain & type & no & 0 & yes & 50 \\
\hline Average total journey time & 2.5 & hours & & & & \\
\hline Labour & driver & type & yes & 100 & no & 0 \\
\hline Transporter & curtain & type & no & 0 & yes & 50 \\
\hline $\begin{array}{c}\text { Tonnes dry matter carried by } \\
\text { the transporter }\end{array}$ & 30 & $\mathrm{tdm}$ & & & & \\
\hline
\end{tabular}


Table A4. Labour costs.

\begin{tabular}{|c|c|c|c|c|c|c|}
\hline Variable & Value & Units & $\begin{array}{c}\text { Labour, Materials, } \\
\text { Machinery }\end{array}$ & If yes & If no, were & If yes, \\
\hline & & & From region? & $\begin{array}{c}\text { what } \\
\% ?\end{array}$ & $\begin{array}{c}\text { from } \\
\text { country? }\end{array}$ & $\begin{array}{l}\text { what } \\
\% ?\end{array}$ \\
\hline Regular farm labour & 5 & $€ / h$ & yes & 100 & no & 0 \\
\hline Contract/casual farm labour & 6 & $€ / h$ & yes & 100 & no & 0 \\
\hline Farmer/spouse labour & 5 & $€ / h$ & yes & 100 & no & 0 \\
\hline Transport driver & 8 & $€ / h$ & yes & 100 & no & 0 \\
\hline Construction plant engineer & 10 & $€ / h$ & no & 0 & yes & 100 \\
\hline Construction plant labour & 8 & $€ / \mathrm{h}$ & yes & 50 & yes & 50 \\
\hline Bioenergy plant operator & 10 & $€ / \mathrm{h}$ & yes & 25 & yes & 75 \\
\hline Bioenergy plant engineer & 20 & $€ / \mathrm{h}$ & no & 0 & yes & 100 \\
\hline Average gross wages & 60,000 & $€ / \mathrm{h}$ & & & & \\
\hline Agriculture sector gross wages & 30,000 & $€ / h$ & & & & \\
\hline Energy sector gross wages & 50,000 & $€ / h$ & & & & \\
\hline Rate of unemployment pay & 12,000 & $€ / h$ & & & & \\
\hline
\end{tabular}

Table A5. Farm machinery costs.

\begin{tabular}{|c|c|c|c|c|c|c|c|c|c|}
\hline Variable & CAPEX & Life & Usage & Maint'an & Fuel & $\begin{array}{c}\text { Lab, mat/ls, } \\
\text { Mach from } \\
\text { Region? }\end{array}$ & $\begin{array}{l}\text { If No, Were } \\
\text { from Country }\end{array}$ & If yes, & $\begin{array}{c}\text { Mach } \\
\text { Cost }\end{array}$ \\
\hline & $(€)$ & (h) & $(\mathrm{h} / \mathrm{y})$ & $(€ / h)$ & $(\mathrm{l} / \mathrm{h})$ & & $?$ & $\begin{array}{c}\text { what } \\
\% ?\end{array}$ & $(€ / \mathrm{h})$ \\
\hline Tractor & 80,000 & 10,000 & 1500 & 3.5 & 8 & no & yes & 100 & 22.84 \\
\hline Trailer & 6888 & 4610 & 922 & 1.57 & 0 & no & yes & 100 & 3.54 \\
\hline Plough & 2,000 & 1200 & 100 & 4.5 & 9 & no & yes & 100 & 16.44 \\
\hline Sub-soiler & 6500 & 1000 & 100 & 3.8 & 10 & no & yes & 100 & 24.38 \\
\hline Disc & 1500 & 1200 & 100 & 3.6 & 7 & no & yes & 100 & 12.80 \\
\hline Harrow & 1500 & 1200 & 100 & 3.6 & 7 & no & yes & 100 & 12.80 \\
\hline Planter & 4000 & 2600 & 240 & 1.6 & 1 & no & yes & 100 & 5.19 \\
\hline Fertiliser distributor & 800 & 900 & 100 & 2.6 & 2 & no & yes & 100 & 5.99 \\
\hline Sprayer & 1500 & 900 & 100 & 1.7 & 1 & no & yes & 100 & 5.30 \\
\hline Irrigator & 15,000 & 900 & 100 & 3.4 & 0.5 & no & yes & 100 & 29.95 \\
\hline Forage Harvester & 50,000 & 5600 & 1124 & 4 & 51 & no & yes & 100 & 66.77 \\
\hline Combined harvester & 275,500 & 5040 & 720 & 55.48 & 42.5 & no & no & 0 & 176.58 \\
\hline Chipper & 174,000 & 7008 & 2336 & 34.64 & 30.6 & no & no & 0 & 95.19 \\
\hline Transporter & 32,866 & 16,380 & 2340 & 6.09 & 21.9 & no & no & 100 & 44.01 \\
\hline
\end{tabular}

\section{Appendix B. Output Model Estimates per Value Chain (All Financial Data in €)}

Table A6. Net impacts from the cultivation of Miscanthus for small scale CHP; 1 MWe.

\begin{tabular}{|c|c|c|c|c|c|c|}
\hline $\mathrm{t} \mathrm{dm} / \mathrm{ha}$ & 10 & 11 & 12 & 13 & 14 & 15 \\
\hline $\begin{array}{l}\text { Area } \\
\text { Direct }\end{array}$ & 550 & 500 & 458 & 423 & 393 & 367 \\
\hline Labour income relating to Capital Investment & 2,922 & 2656 & 2,435 & 2248 & 2,087 & 1948 \\
\hline Jobs relating to Capital Investment & 0.1 & 0.1 & 0.1 & 0.1 & 0.1 & 0.1 \\
\hline $\begin{array}{c}\text { Labour income relating to Operation \& } \\
\text { Maintenance }\end{array}$ & 96,250 & 87,500 & 80,208 & 74,038 & 68,750 & 64,167 \\
\hline & 99,172 & 90,156 & 82,643 & 76,286 & 70,837 & 66,115 \\
\hline Jobs relating to Operation \& Maintenance & 2.8 & 2.5 & 2.3 & 2.1 & 2.0 & 1.8 \\
\hline Annual Profit (Less interest) & 38,000 & 100,800 & 153,000 & 197,300 & 235,200 & 268,000 \\
\hline $\begin{array}{c}\text { Total direct FTEs per value chain } \\
\text { Indirect }\end{array}$ & 2.90 & 2.60 & 2.40 & 2.20 & 2.10 & 1.90 \\
\hline Total Annualised Purchases of Capital Goods & $2,426,161$ & $2,205,601$ & $2,021,801$ & $1,866,278$ & $1,732,972$ & $1,617,441$ \\
\hline Capital Goods Purchased in the Region & $1,503,920$ & $1,367,200$ & $1,253,267$ & $1,156,862$ & $1,074,229$ & $1,002,613$ \\
\hline Indirect jobs & 50.1 & 45.6 & 41.8 & 38.6 & 35.8 & 33.5 \\
\hline $\begin{array}{c}\text { Total Annual Purchases of Operating Goods in } \\
\text { the Region }\end{array}$ & 220 & 200 & 183 & 169 & 157 & 147 \\
\hline
\end{tabular}


Table A7. Net impacts from the cultivation of Miscanthus for Fast Pyrolysis Biomass Oil; 20,000 tonnes/year.

\begin{tabular}{|c|c|c|c|c|c|c|}
\hline $\mathrm{t} \mathrm{dm} / \mathrm{ha}$ & 10 & 11 & 12 & 13 & 14 & 15 \\
\hline $\begin{array}{l}\text { Area } \\
\text { Direct }\end{array}$ & 3000 & 2727 & 2500 & 2308 & 2143 & 2000 \\
\hline Labour income relating to Capital Investment & 28,125 & 25,568 & 23,438 & 21,635 & 20,089 & 18,750 \\
\hline Jobs relating to Capital Investment & 1.4 & 1.3 & 1.2 & 1.1 & 1.0 & 0.9 \\
\hline $\begin{array}{l}\text { Labour income relating to Operation \& } \\
\text { Maintenance }\end{array}$ & 525,000 & 477,273 & 437,500 & 403,846 & 375,000 & 350,000 \\
\hline & 553,125 & 502,841 & 460,938 & 425,481 & 395,089 & 368,750 \\
\hline Jobs relating to Operation \& Maintenance & 26.3 & 23.9 & 21.9 & 20.2 & 18.8 & 17.5 \\
\hline Annual Profit (Less interest) & 374,000 & 701,000 & 973,200 & $1,203,800$ & $1,401,000$ & $1,572,600$ \\
\hline $\begin{array}{c}\text { Total direct FTEs per value chain } \\
\text { Indirect }\end{array}$ & 27.70 & 25.20 & 23.10 & 21.30 & 19.80 & 18.40 \\
\hline Total Annualised Purchases of Capital Goods & $11,950,460$ & $10,864,054$ & $9,958,716$ & $9,192,661$ & $8,536,043$ & $7,966,973$ \\
\hline Capital Goods Purchased in the Region & $8,203,200$ & $7,457,455$ & $6,836,000$ & $6,310,154$ & $5,859,429$ & $5,468,800$ \\
\hline Indirect jobs & 273.0 & 249.0 & 228.0 & 210.0 & 195.0 & 182.5 \\
\hline $\begin{array}{c}\text { Total Annual Purchases of Operating Goods in } \\
\text { the Region }\end{array}$ & 1,200 & 1,091 & 1,000 & 923 & 857 & 800 \\
\hline
\end{tabular}

\section{References}

1. García-Ruiz, J.M.; Nadal-Romero, E.; Lana-Renault, N.; Beguería, S. Erosion in Mediterranean landscapes: Changes and future challenges. Geomorphology 2013, 198, 20-36. [CrossRef]

2. Moore, F.C.; Lobell, D.B. The fingerprint of climate trends on European crop yields. Proc. Natl. Acad. Sci. USA 2015, 112, 2670-2675. [CrossRef] [PubMed]

3. ECOTEC. The Impact of Renewables on Employment and Economic Growth: Final Report; Eufores: Bruxelles, Belgium, 1999.

4. Thornley, P.; Rogers, J.; Huang, Y. Quantification of employment from biomass power plants. Renew. Energy 2008, 33, 1922-1927. [CrossRef]

5. Mantziaris, S.; Iliopoulos, C.; Theodorakopoulou, I.; Petropoulou, E. Perennial energy crops vs. durum wheat in low input lands: Economic analysis of a Greek case study. Renew. Sustain. Energy Rev 2017, 80, 789-800. [CrossRef]

6. Valentine, J.; Clifton-Brown, J.; Hastings, A.; Robson, P.; Allison, G.; Smith, P. Food vs. fuel: The use of land for lignocellulosic "next generation" energy crops that minimize competition with primary food production. GCB Bioenergy 2012, 4, 1-19. [CrossRef]

7. Whitaker, J.; Field, J.L.; Bernacchi, C.J.; Cerri, C.E.P.; Ceulemans, R.; Davies, C.A.; DeLucia, E.H.; Donnison, I.S.; McCalmont, J.P.; Paustian, K. Consensus, uncertainties and challenges for perennial bioenergy crops and land use. GCB Bioenergy 2017. [CrossRef]

8. Cattaneo, F.; Di Gennaro, P.; Barbanti, L.; Giovannini, C.; Labra, M.; Moreno, B.; Benitezc, E.; Marzadori, C. Perennial energy cropping systems affect soil enzyme activities and bacterial community structure in a South European agricultural area. Appl. Soil Ecol. 2014, 84, 213-222. [CrossRef]

9. Gioacchini, P.; Cattaneo, F.; Barbanti, L.; Montecchio, D.; Ciavatta, C.; Marzadori, C. Carbon sequestration and distribution in soil aggregate fractions under Miscanthus and giant reed in the Mediterranean area. Soil Tillage Res. 2016, 163, 235-242. [CrossRef]

10. Lewandowski, I.; Scurlock, J.M.O.; Lindvall, E.; Christou, M. The development and current status of Perennial Rhizomatous grasses as energy crops in the US and Europe. Biomass Bioenergy 2003, 25, 335-361. [CrossRef]

11. Rettenmaier, N.; Köppen, S.; Gärtner, S.O.; Reinhardt, G.A. Life cycle assessment of selected future energy crops for Europe. Biofuels Bioprod. Biorefin. 2010, 4, 620-636. [CrossRef]

12. Nazli, R.I.; Tansi, V.; Öztürk, H.H.; Kusvuran, A. Miscanthus, switchgrass, giant reed, and bulbous canary grass as potential bioenergy crops in a semi-arid Mediterranean environment. Ind. Crop. Prod. 2018, 125, 9-23. [CrossRef]

13. Cosentino, S.L.; Patanè, C.; Sanzone, E.; Copani, V.; Foti, S. Effect of soil water content and nitrogen supply on the productivity of Miscanthus $\times$ Giganteus Greef and Deu. in Mediterranean environment. Ind. Crop. Prod. 2007, 25, 75-88. [CrossRef] 
14. Monti, A.; Zanetti, F.; Scordia, D.; Testa, G.; Cosentino, S.L. What to harvest when? Autumn, winter, annual and biennial harvesting of giant reed, Miscanthus and switchgrass in northern and southern Mediterranean area. Ind. Crops Prod. 2015, 75, 129-134. [CrossRef]

15. Christou, M.; Papavassiliou, D.; Alexopoulou, E.; Chatziathanassiou, A. Comparative studies of two potential energy crops in Greece. In Biomass for Energy and the Environment Proceedings of the 10th European Bioenergy Conference, Wurzburg, Germany, 8-11 June 1998; Kopetz, H., Weber, T., Palz, W., Chartier, P., Ferrero, G.L., Eds.; C.A.R.M.E.N.: Rimpar, Germany, 1998; pp. 935-938.

16. Danalatos, N.G.; Dalianis, C.; Kyritsis, S. Growth and biomass productivity of Miscanthus sinensis "giganteus" under optimum cultural management in north-eastern Greece. In Biomass for Energy and the Environment, Proceedings of the 9th European Bioenergy Conference, Copenhagen, Denmark, 24-27 June 1996; Chartier, P., Ferrero, G.L., Henius, U.M., Hultberg, S., Sachau, J., Wiinblad, M., Eds.; Pergamon: New York, NY, USA, 1996; pp. 548-553.

17. Danalatos, N.G.; Archontoulis, S.V.; Mitsios, I. Potential growth and biomass productivity of Miscanthus $\times$ giganteus as affected by plant density and N-fertilization in central Greece. Biomass Bioenergy 2007, 31, 145-152. [CrossRef]

18. Alexopoulou, E.; Zanetti, F.; Scordia, D.; Zegada-Lizarazu, W.; Christou, M.; Testa, G.; Cosentino, S.L.; Monti, A. Long-term yields of switchgrass, giant reed, and Miscanthus in the Mediterranean basin. Bioenergy Res. 2015, 8, 1492-1499. [CrossRef]

19. Mantineo, M.; Agosta, G.M.D.; Copani, V.; Patane, C.; Cosentino, S.L. Biomass yield and energy balance of three perennial crops for energy use in the semiarid Mediterranean environment. Field Crop. Res. 2009, 114, 204-213. [CrossRef]

20. Pedroso, G.M.; Hutmacher, R.B.; Putnam, D.; Six, J.; Kessel, C.V.; Linquist, B.C. Biomass yield and nitrogen use of potential C4 and C3 dedicated energy crops in a Mediterranean climate. Field Crops Res. 2014, 161, 149-157. [CrossRef]

21. Zanetti, F.; Scordia, D.; Calcagno, S.; Acciai, M.; Grasso, A.; Cosentino, S.L.; Monti, A. Trade-off between harvest date and lignocellulosic crop choice for advanced biofuel production in the Mediterranean area. Ind. Crop. Prod. 2019, 138, 111439. [CrossRef]

22. Convery, I.; Robson, D.; Ottitsch, A.; Long, M. The willingness of farmers to engage with bioenergy and woody biomass production: A regional case study from Cumbria. Energy Policy 2012, 40, 293-300. [CrossRef]

23. Skevas, T.; Hayden, N.J.; Swinton, S.M.; Lupi, F. Landowner willingness to supply marginal land for bioenergy production. Land Use Policy 2016, 50, 507-517. [CrossRef]

24. De la Rúa, C.; Lechon, Y. An integrated multi-regional input-output (MRIO) analysis of miscanthus biomass production in France: Socio-economic and climate change consequences. Biomass Bioenergy 2016, 94, 21-30. [CrossRef]

25. Chazara, P.; Negny, S.; Montastruc, L. Quantitative method to assess the number of jobs created by production systems: Application to multi-criteria decision analysis for sustainable biomass supply chain. Sustain. Prod. Consum. 2017, 12, 134-154. [CrossRef]

26. European Commission. Agriculture: Apartnership between Europe and farmers. 2017. Available online: https:/op.europa.eu/en/publication-detail/-/publication/f08f5f20-ef62-11e6-8a35-01aa75ed71a1 (accessed on 19 May 2020).

27. Key Policy Objectives of the Future CAP. Available online: https://ec.europa.eu/info/food-farmingfisheries/key-policies/common-agricultural-policy/future-cap/key-policy-objectives-future-cap_en (accessed on 21 April 2020).

28. The revised Renewable Energy Directive. Available online: https://ec.europa.eu/energy/sites/ener/files/ documents/directive_renewable_factsheet.pdf (accessed on 21 April 2020).

29. Chiaramonti, D.; Panoutsou, C. Policy measures for sustainable sunflower cropping in EU-MED marginal lands amended by biochar: Case study in Tuscany, Italy. Biomass Bioenergy 2019, 126, 199-210. [CrossRef]

30. Casini, D.; Barsali, T.; Rizzo, A.M.; Chiaramonti, D. Production and characterization of co-composted biochar and digestate from biomass anaerobic digestion. Biomass Conv. Bioref. 2019. [CrossRef]

31. Fernando, A.L.; Costaa, J.; Barbosaab, B.; Montic, A.; Rettenmaier, N. Environmental impact assessment of perennial crops cultivation on marginal soils in the Mediterranean Region. Biomass Bioenergy 2018. [CrossRef]

32. Zafeiriou, E.; Petridis, K.; Karelakis, C.; Arabatzis, G. Optimal combination of energy crops under different policy scenarios; The case of Northern Greece. Energy Policy 2016, 96, 607-616. [CrossRef] 
33. Fontaras, G.; Skoulou, V.; Zanakis, G.; Zabaniotou, A.; Samaras, Z. Integrated environmental assessment of energy crops for biofuel and energy production in Greece. Renew. Energy 2012, 43, 201-209. [CrossRef]

34. Haque, M.; Epplin, F.M.; Taliaferro, C.M. Nitrogen and harvest frequency effect on yield and cost for four perennial grasses. Agron. J. 2009. [CrossRef]

35. Triana, F.; Nassi o Di Nasso, N.; Ragaglini, G.; Roncucci, N.; Bonari, F. Evapotranspiration, crop coefficient and water use efficiency of giant reed (Arundo donax L.) and Miscanthus (Miscanthus $\times$ giganteus Greef et Deu.) in a Mediterranean environment. Glob. Chang. Biol. Bioenergy 2014. [CrossRef]

36. Knoll, J.E.; Anderson, W.F.; Strickland, T.C.; Hubbard, R.K.; Malik, R. Low-input production of biomass from perennial grasses in the coastal plain of Georgia, USA. Bioenergy Res. 2012, 5, 206-214. [CrossRef]

37. Kering, M.K.; Butler, T.J.; Biermacher, J.T.; Guretzky, J.A. Biomass yield and nutrient removal rates of perennial grasses under nitrogen fertilization. Bioenergy Res. 2012, 5, 61-70. [CrossRef]

38. Mauromicale, G.; Sortino, O.; Pesce, G.R.; Agnello, M.; Mauro, R.P. Suitability of cultivated and wild cardoon as a sustainable bioenergy crop for low input cultivation in low quality Mediterranean soils. Ind. Crop. Prod. 2014, 57, 82-89. [CrossRef]

39. Monti, A.; Zatta, A. Root distribution and soil moisture retrieval in perennial and annual energy crops in northern Italy. Agric. Ecosyst. Environ. 2009, 132, 252-259. [CrossRef]

40. Hecht, I. The Plant Encyclopedia: The Global Guide to Cultivated Plants. 2011. Available online: http: //theplantencyclopedia.org (accessed on 2 February 2015).

41. Lewandowski, I.; Clifton-Brown, J.; Scurlock, J.; Huisman, W. Miscanthus: European experience with a novel energy crop. Biomass Bioenergy 2000, 19, 210. [CrossRef]

42. Lesur, C.; Jeuffroy, M.H.; Makowski, D.; Riche, A.B.; Shield, I.; Yates, N.; Fritz, M.; Formowitz, B.; Grunert, M.; Jorgensen, U.; et al. Modeling long-term yield trends of Miscanthus $\times$ giganteus using experimental data from across Europe. Field Crops Res. 2013, 149, 252-260. [CrossRef]

43. Skousen, J.; Brown, C.B.; Griggs, T.; Byrd, S. Establishment and growth of switchgrass and other biomass crops on surface mines. JASMR 2014, 3, 136-156. [CrossRef]

44. Amaducci, S.; Facciotto, G.; Bergante, S.; Perego, A.; Serra, P.; Ferrarini, A.; Chimento, C. Biomass production and energy balance of herbaceous and woody crops on marginal soils in the Po valley. GCB Bioenergy 2017, 9, 31-45. [CrossRef]

45. Angelini, L.G.; Ceccarini, L.; Di Nasso, N.N.; Bonari, E. Comparison of Arundo donax L. and Miscanthus x giganteus in a long-term field experiment in Central Italy: Analysis of productive characteristics and energy balance. Biomass Bioenergy 2009, 33, 635-643. [CrossRef]

46. Clifton-Brown, J.C.; Stampfl, P.F.; Jones, M.B. Miscanthus biomass production for energy in Europe and its potential contribution to decreasing fossil fuel carbon emissions. Glob. Change Biol. Bioenergy 2004, 10, 509-518. [CrossRef]

47. Soldatos, P.G. Economic aspects of bioenergy production from perennial grasses in marginal lands of South Europe. Bioenergy Res. 2015, 8, 1562-1573. [CrossRef]

48. Forbio. D 2.1 Feasibility Study: Italy Agronomic Feasibility. Fostering Sustainable Feedstock Production for Advance Biofuels on Underutilized Land in Europe. 2016. Available online: http://www.forbio-project.eu/ assets/content/publication/FORBIO_D21_approved.pdf (accessed on 20 May 2020).

49. Kretschmer, B.; Desbarats, J. Biomass Futures: Analysis of Issues and Concerns for Policy Makers in Terms of Implementing Bioenergy Requirements (Deliverable 6.3 under Biomass Futures). 2012. Available online: www.biomassfutures.eu (accessed on 20 May 2020).

50. BTG. Available online: https://www.btg-btl.com/en/technology (accessed on 21 April 2020).

51. The Land Institute. Perennial Grain Cropping Research: Why Perennial Grain Crops? Perennial Grain Cropping Research: Why Perennial Grain Crops? 2016. Available online: https://landinstitute.org/our-work/ perennial-crops/ (accessed on 21 April 2020).

52. Wahlquist, A. Perennial crops a win for food security. Australian 2011, 2, 32-34.

53. Pelkmans, L.; Guisson, R.; Elbersen, B.; Panoutsou, C. SWOT Analysis of Biomass Value Chains. Deliverable 2.4 of the Biomass Policies Project 2016. Available online: www.biomasspolicies.eu (accessed on 21 April 2020).

54. Dale, V.H.; Kline, K.L.; Wiens, J.; Fargione, J. Biofuels: Implications for Land Use and Biodiversity; The Ecological Society of America: Washington, DC, USA, 2010.

55. Domac, J.; Richards, K.; Risovic, S. Socio-economic drivers in implementing bioenergy projects. Biomass Bioenergy 2005, 28, 97-106. [CrossRef] 
56. Miller, R.E.; Blair, P.D. Input-output Analysis: Foundations and Extensions, 2nd ed.; Cambridge University Press: Cambridge, UK, 2009.

57. FES. Socio-Economic Multiplier Model for Rural Diversification Through Biomass Energy deployment-BIOSEM Model: Final Report; European Commission: Brussels, Belgium, 1999.

58. Panoutsou, C. Socio-economic impacts of energy crops for heat generation in Northern Greece. Energy Policy 2007, 35, 6046-6059. [CrossRef]

59. Investopedia. What Is the Keynesian Multiplier? Available online: http://www.investopedia.com/ask/ answers/09/keynesian-multiplier.asp (accessed on 20 April 2020).

60. Ramirez-Almeyda, J.; Elbersen, B.; Monti, A.; Staritsky, I.; Panoutsou, K.; Alexopoulou, E.; Schrijver, R.; Elbersen, W. Assessing the potentials for non food crops. In Modeling and Optimization of Biomass Supply Chains; Top-down and Bottom-up assessment for agricultural, forest and waste feedstock; Panoutsou, K., Ed.; Academic Press, Elsevier: London, UK, 2017.

61. Ercoli, L.; Mariotti, M.; Masoni, A.; Bonari, E. Effect of irrigation and nitrogen fertilization on biomass yield an efficiency of energy in crop production of Miscanthus. Field Crops Res. 1999, 63, 3-11. [CrossRef]

62. Fazio, S.; Barbanti, L. Energy and economic assessments of bio-energy systems based on annual and perennial crops for temperate and tropical areas. Renew. Energy 2014, 69, 233-241. [CrossRef]

63. Kandel, T.P.; Hastings, A.; Jorgensen, U.; Olesen, J.E. Simulation of biomass yield of regular and chilling tolerant Miscanthus cultivars and reed canary grass in different climates of Europe. Ind. Crop. Prod. 2016, 86, 329-333. [CrossRef]

64. Panoutsou, C.; Alexopoulou, E. Costs and profitability of crops for bioeconomy in the EU. Energies 2020, 13, 1222. [CrossRef]

65. IEA. Technology Roadmap-Biofuels for Transport. International Energy Agency, Paris. 2011. Available online: https://www.ieabioenergy.com/wp-content/uploads/2013/10/IEA-Biofuel-Roadmap.pdf (accessed on 21 April 2020).

66. IEA. Technology Roadmap: Bioenergy for Heat and Power. International Energy Agency, Paris. 2012. Available online: http://www.globalbioenergy.org/uploads/media/1205_IEA_-_Technology_Roadmap_ Bioenergy_for_Heat_and_Power_.pdf (accessed on 21 April 2020).

67. Vamvuka, D.; Topouzi, V.; Stratakis, A.; Christou, M.; Alexopoulou, E.; Panoutsou, C. Giant reed as a fuel for heat and electricity applications in Greece. In Proceedings of the 15th European Biomass Conference, Berlin, Germany, 7-11 May 2007.

68. Vamvuka, D.; Topouzi, D.; Sfakiotakis, S.; Pentari, D.; Christou, M. Production yield and combustion characteristics of cardoon grown as a potential feedstock for energy applications in Greece. In Proceedings of the 17th European Biomass Conference, Hamburg, Germany, 29 June-3 July 2009.

69. Pantaleo, A.; Pellerano, A.; Carone, M.T. Potentials and feasibility assessment of small scale CHP plants fired by energy crops in Puglia region (Italy). Biosyst. Eng. 2016, 102, 345-359. [CrossRef]

70. Vamvuka, D.; Topouzi, V.; Sfakiotakis, S. Evaluation of production yield and thermal processing of switchgrass as a bio-energy crop for the Mediterranean region. Fuel Process. Technol. 2010, 91, 988. [CrossRef]

71. Karampinis, E.; Vamvuka, D.; Sfakiotakis, S.; Grammelis, P.; Itskos, G.; Kakaras, E. Comparative study of combustion properties of five energy crops and Greek lignite. Energy Fuels 2012, 26, 869-878. [CrossRef]

72. Bridgwater, A.V. Biomass Pyrolysis. IEA Bioenergy, October 2010. Available online: http://www.ieabioenergy.com/ wp-content/uploads/2013/10/ExCo66-P2-Biomass-pyrolysis-Tony-Bridgwater1.pdf (accessed on 21 April 2020).

73. Jeguirim, M.; Trouvé, G. Pyrolysis characteristics and kinetics of Arundo donax using thermogravimetric analysis. Bioresour. Technol. 2009, 100, 4026-4031. [CrossRef] [PubMed]

74. Lee, S.B.; Fasina, O. TG-FTIR analysis of switchgrass pyrolysis. J. Anal. Appl. Pyrolysis 2009, 86, 39. [CrossRef]

75. Damartzis, T.; Vamvuka, D.; Sfakiotakis, S.; Zabaniotou, A. Thermal degradation studies and kineticmodeling of cardoon (Cynara cardunculus) pyrolysis using thermogravimetric analysis (TGA), Bioresour. Technol. 2011, 102, 6230-6238. [CrossRef]

76. Vamvuka, D.; Sfakiotakis, S. Effects of heating rate and water leaching of perennial energy crops on pyrolysis characteristics and kinetics. Renew. Energy 2011, 36, 2433-2439. [CrossRef]

77. Mos, M.; Banks, S.W.; Nowakowski, D.J.; Robson, P.R.H.; Bridgwater, A.V.; Donnison, I.S. Impact of Miscanthus $\times$ Giganteus senescence times on fast pyrolysis bio-oil quality. Bioresour. Technol. 2013, 129, 335-342. [CrossRef] 
78. Mimmo, T.; Panzacchi, P.; Baratieri, M.; Davies, C.A.; Tonon, G. Effect of pyrolysis temperature on Miscanthus (Miscanthus $\times$ Giganteus) biochar physical, chemical and functional properties. Biomass Bioenergy 2014, 62, 149-157. [CrossRef]

79. Cortes, A.M.; Bridgwater, A.V. Kinetic study of the pyrolysis of Miscanthus and its acid hydrolysis residue by thermogravimetric analysis. Fuel Process. Technol. 2015, 138, 184-193. [CrossRef]

80. Jayaraman, K.; Gökalp, I. Pyrolysis, combustion and gasification characteristics of Miscanthus and sewage sludge. Energy Convers. Manag. 2015, 89, 83-91. [CrossRef]

81. Pinho, A.; de Almeida, M.B.B.; Mendes, F.L.; Casavechia, L.C.; Talmadge, M.S.; Kinchin, C.M.; Chum, H.L.; De Rezende, A.; Leal, F.; Carlos, L. Fast pyrolysis oil from pinewood chips co-processing with vacuum gas oil in an FCC unit for second generation fuel production. Fuel 2017, 188, 462-473. [CrossRef]

82. De Mercader, M.F.; Groeneveld, M.J.; Kersten, S.R.A.; Way, N.W.J.; Schaverien, C.J.; Hogendoorn., J.A. Production of advanced biofuels: Co-processing of upgraded pyrolysis oil in standard refinery units. Appl. Catal. B Environ. 2010, 96, 57-66. [CrossRef]

83. ETIP Bioenergy. Available online: http://www.etipbioenergy.eu/value-chains/conversion-technologies/ advanced-technologies/co-processing-in-refineries (accessed on 21 April 2020).

84. Biofuels Procurement Production Costs. Available online: http://www.eubia.org/cms/wiki-biomass/biofuelsprocurement-production-costs/ (accessed on 21 April 2020).

85. FORBIO. Available online: www.forbio-project.eu (accessed on 21 April 2020).

86. SEEMLA. Available online: https://www.seemla.eu/home/ (accessed on 21 April 2020).

87. MAGIC. Available online: https://magic-h2020.eu/ (accessed on 21 April 2020).

88. Baumgarten, W.; Panoutsou, C.; Gerwin, W. Growing Perennial Crops on Marginal Land in Europe for Bioenergy; Agency for Renewable Resources: Gülzow, Germany, 2020.

89. BTG. Available online: https://www.btg-btl.com/en/company/product (accessed on 21 April 2020).

90. Panoutsou, C. The role of sustainable biomass in the heat market sector for EU27. Wiley Interdisciplinary. Rev. Energy Environ. 2016, 5, 430-450. [CrossRef]

91. ETI. An ETI Perspective. Opportunities for Rural Job Creation in the UK Energy Crops Sector. 2017. Available online: http://www.eti.co.uk/library (accessed on 21 April 2020).

92. EUBIA. Available online: http://www.eubia.org/cms/wiki-biomass/biofuels-procurement-production-costs/ (accessed on 21 April 2020).

93. Pollin, R.; Heintz, J.; Garrett-Peltier, H. The Economic Benefits of Investing in Clean Energy; Department of Economics and Political Economy Research Institute (PERI): Amherst, MA, USA, 2009.

94. Fraunhofer ISI, 2009. EmployRES. The Impact of Renewable Energy Policy on Economic Growth and employment in the European Union. Available online: https:/ec.europa.eu/energy/sites/ener/files/documents/ 2009_employ_res_report.pdf (accessed on 21 April 2020).

95. European Commission. Available online: https:/ec.europa.eu/transparency/regdoc/rep/3/2019/EN/C-20192055-F1-EN-ANNEX-1-PART-1.PDF (accessed on 20 April 2020).

96. European Commission. Regulations Commission Delegated Regulation (EU) 2019/807. Available online: https:/eur-lex.europa.eu/legal-content/EN/TXT/PDF/?uri=CELEX:32019R0807 (accessed on 20 April 2020).

97. European Commission. Renewable Energy-Recast to 2030 (Red II). Available online: https://ec.europa.eu/jrc/ en/jec/renewable-energy-recast-2030-red-ii (accessed on 20 April 2020).

98. European Commission. Key policy objectives of the future CAP. Available online: https://ec.europa.eu/info/ sites/info/files/food-farming-fisheries/key_policies/documents/cap-specific-objectives-brief-4-agriculture-andclimate-mitigation_en.pdf (accessed on 20 April 2020).

99. Panoutsou, C.; Singh, A. A value chain approach to improve biomass policy formation. Glob. Chang. Biol. Bioenergy 2020. [CrossRef]

(C) 2020 by the authors. Licensee MDPI, Basel, Switzerland. This article is an open access article distributed under the terms and conditions of the Creative Commons Attribution (CC BY) license (http://creativecommons.org/licenses/by/4.0/). 